\title{
CHOOSING THE RIGHT WORDS: INTERPRETING RENT REVIEW AND RENEWAL CLAUSES IN COMMERCIAL LEASES
}

\author{
GARY R. MENZIES*
}

This article examines the various ways that courts have interpreted rent review and rent renewal clauses in commercial leases. Both the subjective and objective approaches are discussed and cases illustrative of these approaches are examined. The author then outlines the implications of restriction on use clauses in this area; case law is discussed and practical drafting hints are suggested. Finally, sample rent renewal clauses are provided, favourable to both landlord and tenant respectively.
Le présent article traite des diverses façons dont les tribunaux interprètent les clauses relatives à la révision des loyers et au renouvellement des baux commerciaux. Les approches subjectives et objectives sont traitées - exemples à l'appui. $L$ 'auteur souligne ensuite les implications des clauses édictant les restrictions d'utilisation. La jurisprudence est examinée el certaines suggestions pratiques de rédaction sont proposées. Enfin, des exemples de clauses de renouvellement sont offerts, favorables au propriétaire et au locataire respectivement.

\section{TABLE OF CONTENTS}

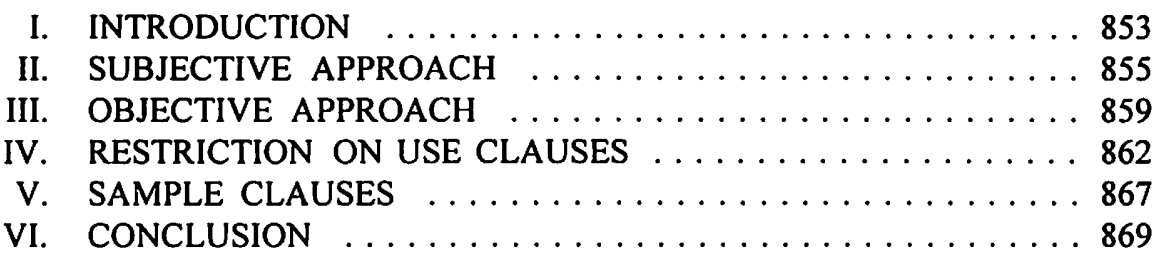

\section{INTRODUCTION}

Drafting rent review and renewal clauses in commercial leases has become a precise art. Recent cases reveal the importance of accurate and comprehensive drafting of these clauses. Poorly worded or designed clauses can result in prolonged litigation or arbitration over the meaning of certain words and can cost both landlord and tenant a great deal of time and money. Drafters should carefully set out with precision and clarity what standard is to be used in determining the rent payable for a review period or renewal term under a commercial lease. If the rent is to be assessed based on what is a "fair market rent" for the leased premises, the term "fair market rent" should be defined so that the parties or an arbitrator have some direction as to what factors to take into account in determining the "fair market rent." Similarly, if the rent is to be assessed on some basis other than a "fair market rent," such as what is a "reasonable" or "fair" rent as between the landlord and the tenant, drafters should specifically set out what factors the parties or an arbitrator may take into account in arriving at a "reasonable" or "fair" rent.

Rent review clauses are commonly found in long term leases which call for periodic rent reviews. Rent renewal clauses, on the other hand, are found in either short term or long term leases where a landlord desires to grant to a tenant an option to renew a lease 
on the same terms and conditions for an additional period. Both clauses are often comprised of two basic components. First, they provide that a landlord and a tenant shall, within a certain period set out in the lease, agree upon the rent payable for a review period or renewal term. Secondly, if the parties are unable to agree upon the rent payable within a period set out in the lease, there is a mechanism to determine the rent payable which is usually by arbitration. It is well established that the second component is necessary to create an enforceable obligation on the parties. If the clause simply states that the rent shall be agreed upon by the parties without any mechanism for determining the rent payable in the event that the parties cannot agree, then the courts have held consistently that such a clause is void for uncertainty. ${ }^{\prime}$ Generally speaking, the courts will not compel the parties to accept an amount for the rent payable where no mechanism is provided for determining such rent. ${ }^{2}$ While these two components are found in most clauses, subtle differences in drafting can result in significant differences in how these clauses are interpreted and in determining the rent payable under them.

In interpreting rent review or renewal clauses, the courts will generally adopt one of two approaches depending upon the wording of a clause - a subjective approach or an objective approach. ${ }^{3}$ The courts take a subjective approach where a rent review or renewal clause provides that the rent payable shall be based on "a rent to be agreed upon by the parties" or on what is a "fair rent" or "reasonable rent" as agreed between the parties. Under a true subjective clause, there is no reference to the rent being determined based on what is the "market rent" for the leased premises. The scope of

See e.g.: Godson v. P. Burns \& Co., [1919] 1 W.W.R. 848 (S.C.C.); Calford Properties Ltd. v. Kelly's Billiards Lid., [1973] 4 W.W.R. 532 (Alta.S.C.).

2 Where the mechanism for determining the rent payable is left to one party, the courts have found such a clause to be enforceable. See Dagney Development Corp. v. Ocean Fisheries Lid. (1991), 17 R.P.R. (2d) 107 (B.C.S.C.). Where a clause provides that the parties shall mutually agree upon the rent payable, the courts have also imposed an obligation upon the parties to negotiate in good faith. See Empress Towers Lid. v. Bank of N.S. (1990), 50 B.C.L.R. (2d) 126 (B.C.C.A.) [hereinafter Empress Towers]; B.I.H. Invesiments Inc. v. Kim, [1996] B.C.J. No. 49 (QL) [hereinafter B.I.H. Investments]. In Empress Towers, the Court found that the landlord was required to negotiate in good faith even though the rent renewal clause was found to be void for uncertainty since it did not contain a mechanism for determining the rent payable in the event that the parties could not agree. In B.I.H. Investments, the Court may have carved out an exception to the rule that a court will not impose a rent on the parties where the parties cannot agree and where there is no mechanism in the lease to determine the rent payable. In that case, the lease set the rent for the first year and provided that the rent for the remaining four years was to be mutually agreed upon by the paries. While there was no mechanism to determine the rent in the event that the parties could not agree, the Court held that the rent payable for the remainder of the lease was to be based on the market value of the leased premises. In so doing, it distinguished the decision in Empress Towers on the basis that the clause in Empress Towers was a rent renewal clause and the clause in B.I.H. Investments was a rent review clause.

3 For a good discussion on interpreting rent review or renewal clauses see S. Tromans, Commercial Leases (London: Sweet \& Maxwell, 1987) at 48-52. For briefer discussions on interpreting these clauses see also K.J. Glasner "Rent Review Clauses - Subjective or Objective Test" (1989) 47:6 The Advocate (Vancouver, B.C.) at 895; J.A. Titerle, "Rent Reviews - The Role of Tenant's Improvements and the Subjective/Objective Tests" in Commercial Leases - 1995 Update (Vancouver: Continuing Legal Education Society of British Columbia, 1995) at 5.1; A.F. Hilliard, "Options to Renew" in Commercial Leases - 1995 Update, ibid. at 5.2. 
the arbitrator is broad as he may take into account all factors which would be relevant to the negotiations of the parties in determining what is "fair" or "reasonable" as between the particular landlord and the particular tenant involved in the rental negotiations. In contrast, the courts adopt an objective approach where the rent is to be determined based solely on what is the prevailing "market rent" for the leased premises. Under such a clause, an arbitrator must disregard all subjective factors which may be relevant to the landlord and the tenant involved in the arbitration, including the actual occupation of the leased premises by the tenant, and must determine the rent based on what is solely the "market rent" for the leased premises.

\section{SUBJECTIVE APPROACH}

The most basic version of a rent review or renewal clause which calls for a subjective approach provides that the rent for the review period or renewal term shall be determined based on what is a "rent," "reasonable rent" or "fair rent" to be agreed upon by the landlord and the tenant and, failing agreement, to be determined by an arbitrator. While there are many variations of this form of clause, the key component is that there is no reference to a "market rent" and no objective standard upon which the rent is to be fixed either by the parties or by an arbitrator. Without an objective standard, an arbitrator must assess the rent payable based on what is fair or reasonable for both parties involved in the rental negotiations taking into account all factors which would affect the mind of the landlord and the tenant in connection with the negotiation of the rent payable.

The subjective approach usually works for the benefit of the tenant. The tenant may be able to adduce evidence that a "fair" or "reasonable" rent as between the landlord and the tenant is lower than the market rent for the leased premises. For example, if the tenant installed improvements to the leased premises during the previous term, at the tenant's sole expense, and such improvements increased the value of the leased premises, it would not be "fair" or "reasonable" to the tenant to assess the rent payable based on the market rent for the leased premises, as improved. Since the tenant paid for these improvements, the tenant can make a persuasive argument under the subjective approach that the increased value to the leased premises as a result of these improvements should be disregarded completely in order for the rent to be "fair" or "reasonable" to the tenant. This argument has been accepted by the courts in a number of cases. ${ }^{4}$ Similarly, where the tenant has a strong financial covenant, some deduction might be made in the rent payable in recognition of the fact that the tenant is not likely to become insolvent or bankrupt during the term of the lease. By leasing to a tenant with a strong financial covenant, a landlord has a lower risk of having its income stream disrupted during the term of the lease. Furthermore, if the tenant can adduce evidence that it cannot make any profits from the leased premises if it paid market rent for the leased premises, it may be able to argue that some reduction in rent should be 
made since a "fair" or "reasonable" rent to the tenant is a rent which permits the tenant to make a profit.

The subjective approach finds its origins in several cases decided in the 1970s and 1980s. The English Court of Appeal in Thomas Bates \& Son Ltd. v. Wyndham's (Lingerie) $L t d^{5}$ adopted the subjective approach in interpreting a rent review clause which stated that the rent payable shall be "a rent to be agreed between the lessor and the lessee but in default of such agreement at a rent to be fixed by a single arbitrator."6 The question in that case was whether the trial judge adopted the correct approach in assessing the rent payable by finding that the word "rent" meant "market rent" for the leased premises. Counsel for the landlord conceded that, on the true construction of the rent review clause, the rent should be that rent which would have been reasonable for the particular landlord and the particular tenant in the rental dispute to have agreed upon under the lease. It was his contention, however, that market rent was a reasonable rent as between the parties. Counsel for the tenant argued that the word "rent" implied a "fair" rent as between the parties.

While the rent review clause in Thomas Bates did not refer to a "fair" rent or a "reasonable" rent being paid by the tenant, Buckley L.J. held that the term "rent" as used in this clause must be interpreted using a subjective approach. He found that where a clause calls for a rent to be agreed between the parties without any reference to a "market rent," the rent must be assessed based on what is a "fair rent" as between the parties. In finding that the arbitrator could take into account all considerations which would affect the mind of the landlord and the tenant in connection with the negotiation of such rent, Buckley L.J. stated:

So the parties are now at one that, on the true construction of the clause as rectified, the rent is to be fixed by the arbitrator at such amount as it would be reasonable for the parties to agree having regard to all such considerations as I have mentioned. This is not the construction adopted by the judge, who, as appears from the terms of his order, implied a term that the rent to be agreed should be the market rent. His attention had not, of course, been drawn to the decision of this court in Beer v. Bowden. As I understand the position, neither party now contends that the judge's view in that respect is right, and 1 myself am satisfied that the market rent would not provide a proper standard to adopt in the present case. In my judgment, in default of agreement between the parties, the arbitrator would have to assess what rent it would have been reasonable for these landlords and these tenants to have agreed under this lease having regard to all the circumstances relevant to any negotiations between them of a new rent from the review date.

The decision of the English Court of Appeal in Thomas Bates has been applied or followed in a number of cases. ${ }^{8}$ 
Several years prior to the decision in Thomas Bates, the British Columbia Court of Appeal in Lynnwood No. I had adopted a subjective approach in interpreting a rent review clause similar to the one found in Thomas Bates. The rent review clause in Lynnwood No. I provided that the "rent" was to be agreed upon by the parties and, failing agreement, was to be set by arbitration. Counsel for the landlord submitted that the arbitration board had no jurisdiction under the rent review clause to consider any extraneous factors in determining the rent payable except to apply a capitalization rate of eight per cent to the fair market value for the land as of the commencement of the rent review period. Counsel for the tenant argued that the arbitration board was not restricted in its determination of the "rent" to be paid and that it could take into account all facts and circumstances relevant to the landlord and the tenant, including the fact the tenant had made several improvements to the leased premises at the tenant's sole expense.

The arbitration board in Lynnwood No. 1 held that it was not restricted in its determination of the rent to looking at what was merely the fair market rent for the leased premises. The board found that it could consider all evidence adduced before it, including making allowance for the fact that the tenant paid for the improvements made to the premises during the previous review period. The arbitration award was appealed to the British Columbia Supreme Court on the basis of an error of law and the trial judge held that such an approach was incorrect and invalidated the award. The Court of Appeal, in an unanimous decision, overturned the trial judge's decision and upheld the award of the arbitration board on the basis that there was no error of law on the face of the record.

In 1982, the British Columbia Court of Appeal in Lynnwood No. 2 was asked to interpret the same rent review clause in the same lease as in Lynnwood No. 1. The issue again was whether improvements made to the leased premises during the previous rent review period at the expense of the tenant were to be excluded from any calculation of the value of the leased premises and from the determination of the rent payable for the review period. Carrothers J.A. in Lynnwood No. 2 held that the rent was to be determined using the subjective approach since the lease provided that the rent was to be agreed upon by the parties without any reference to a market rent. Carrothers J.A. agreed with the reasoning of the trial judge, Rae J. and found that the improvements made at the expense of the tenant during the previous rental period were to be excluded from the rent calculation. Rae J. succinctly summarized the subjective approach as follows:

review clause in a lease for a container terminal in Halifax stated that the rent was to be at "such rates as may be determined" by the National Harbours Board. On appeal from a decision of the Board, the Court held that subjective elements should be considered in establishing the rent payable. While the Court stated that the market value of the lands and the capital cost recovery to the landlord was one of the factors to be considered, it found that there existed a special relationship between the parties which indicated that the parties had set previous rentals using subjective elements, such as the competitiveness of the Halifax port in comparison to other ports in Montreal and the United States. 
Thus it appears that the matter is to be regarded as between this lessor and this lessee who are the parties to the lease in which the land is already demised; further, that it is a matter of what is appropriate between these parties and not what the property should bring in rent were it then being let afresh. This, of course, has regard to the construction properly to be put upon the relevant clause in the lease."

In rendering his decision, Carrothers J.A. applied the decision of the English Court of Appeal in Thomas Bates.

The decisions in Thomas Bates, Lynnwood No. 1 and Lynnwood No. 2 suggest that where a rent review or renewal clause calls for a "rent," "fair rent" or "reasonable rent" to be agreed upon by the parties, without any objective standard upon which the rent is to be assessed, the arbitrator must apply the subjective approach. While the arbitrator may take into account what is the fair market rent for the leased premises, he must also consider all factors which are relevant in the minds of the parties in assessing what is a "fair" or "reasonable" rent as between the parties. These factors include:

(a) the economic return to the landlord using a capitalization rate based on the market value of the leased premises;

(b) the value of the leased premises to the tenant, including the goodwill established by the tenant in conducting business at the location of the leased premises, and the potential loss of market share in having to relocate to new premises;

(c) the strength of the financial covenant of the tenant since a tenant that has a strong financial covenant is much more valuable to a landlord and will more likely provide the landlord with a constant income stream during the term of the lease;

(d) the economic return to the tenant in carrying on business from the leased premises as the market rent may be too high to enable a tenant to make a profit for the type of business that the tenant carries on from the leased premises; ${ }^{10}$

(e) the type of business carried on by the tenant since certain types of business, such as banks, large department stores or grocery stores will generally command lower rental rates than other retail stores in a shopping mall where the landlord considers such tenants to be "anchor tenants" which are necessary to bring foot traffic to the mall;" and

(1982), 132 D.L.R. (3d) 496 at 505 [emphasis in original].

This factor was considered by the B.C.C.A. in Lynnwood No. $l$ and by the Supreme Court of British Columbia in Knapp (Canada) Lid. v. Crown Forest Industries Ltd. (25 April 1985), Vancouver A850151/A850152 (B.C.S.C.).

" Generally speaking, the lower rental rates paid by banks, large department stores or grocery stores are also due, in part, to the stronger financial covenant of these tenants and the fact that these tenants generally lease larger space than other retail stores. 
(f) whether the tenant paid for any tenant improvements made to the leased premises during the previous review period or lease term which increased the value of the leased premises and resulted in a corresponding increase in the rental rate for the leased premises. ${ }^{12}$

\section{OBJECTIVE APPROACH}

The essential element found in all rent review or renewal clauses which call for an objective approach is a reference to some objective standard upon which the parties or the arbitrator must determine the rent payable. Such clauses will commonly provide that the rent shall be agreed upon by the landlord and the tenant based on what is the "fair market rent" or "open market rent" for the leased premises and, failing agreement, shall be determined by an arbitrator on the same basis. It has become common practice for landlords to limit the arbitrator's scope in a rent review or renewal clause and require that he determine the rent based on what is solely the prevailing market rent for the leased premises as of the date of the assessment. "Market rent" has been defined as "[t]he rental income that a property would most probably command on the open market as indicated by current rentals being paid for comparable space. ${ }^{13}$ These clauses will often expressly state that the "market rent" shall be determined based on what a hypothetical landlord and a hypothetical tenant would pay for the leased premises taking into account the terms of the existing lease between the landlord and the tenant, but excluding certain clauses which might result in any subjective factors being taken into account. Generally, these clauses expressly provide that determination of "market rent" is to be made disregarding the actual occupation of the leased premises by the existing tenant.

Inherent in the objective approach is the comparison of the leased premises to similar properties in the vicinity of the leased premises and the rents negotiated for such premises. Any circumstance which affects the actual landlord and the actual tenant, but which would not affect the hypothetical landlord and tenant, is irrelevant. ${ }^{14}$ This approach was adopted by the majority of the House of Lords in Ponsford and Others v. H.M.S. Aerosols Ltd. ${ }^{\text {15 }}$ The rent review clause in that case stated that the rent for the review period shall be mutually agreed between the parties and, failing such

See e.g. Lynnwood No. I and Lynnwood No. 2. The success of this argument may also depend on when title to the improvements passes from the tenant to the landlord. If title passes upon affixation or if title passes upon the expiration of the term and the parties are negotiating rent for a renewal term, the landlord has a persuasive argument that the tenant's improvements form a part of the leased premises and that the tenant should pay a higher rent where the rent renewal clause refers to rent being determined based on the value of the leased premises. See Leschallas v. Woolf, [1908] 1 Ch. 641; Murray v. Odman (1939), 96 P.2d 489 (Wash.S.C.); Brownell v. Burlington Federal Savings \& Loan Association (1949), 6 A.L.R. 2 d 444 (Vt. S.C.). This would not, however, include tenant's trade fixtures where the tenant is overholding upon the expiration of the term: see New Zealand Government Property v. HM \& S Lid. (1981), [1982] I All E.R. 624 (C.A.). B.N. Boyce, ed., Real Estate Appraisal Terminology (Cambridge, Mass.: Ballinger, 1975) at 136. See F.R. Evans (Leeds) Ltd. v. English Electric Co. Lid. (1977), [1978] 36 P. \& C.R. 185 (Q.B.) for a detailed discussion on the factors which are relevant to a hypothetical landlord and a hypothetical tenant in determining a "market rent" under a lease.

(1978), [1979] 1 A.C. 63 (H.L.) [hereinafter Ponsford]. 
agreement, shall be a "reasonable rent for the demised premises." The issue before the House of Lords was whether the arbitrator, in determining a "reasonable rent for the demised premises," could take into account improvements made to the demised premises during the previous rent review period without considering who paid for such improvements. The tenant had installed the improvements at its sole expense and argued that it was unjust for the arbitrator not to take this fact into consideration. The tenant submitted that the standard to be applied by the arbitrator in assessing the rent payable should have been what was a "reasonable rent" as between the particular landlord and tenant in that case.

The House of Lords in Ponsford, by a 3:2 majority, found in favour of the landlord and held that it was not proper to consider who paid for the improvements. The majority found that the words "reasonable rent for the demised premises" set a standard upon which the arbitrator was to determine the rent payable. This standard called for a determination of what the demised premises might reasonably let for on the open market. Keith L.J. stated:

In my opinion the words "a reasonable rent for the demised premises" simply mean "the rent at which the demised premises might reasonably be expected to let." Considering that the demised premises necessarily include the improvements, to arrive at a lower rent by reason that the tenants paid for the latter would in substance mean that a rent for part only of the demised premises was being assessed. The fact that the assessed rent leads to an unreasonable result as between the particular tenant and the particular landlord does not mean that it is not a reasonable rent for the premises. ${ }^{16}$

\section{Viscount Dilhorne L.J. concurred with Keith L.J.:}

The rent payable by the lessees will of course be rent for the demised premises but as 1 see it, the task of the surveyor is not to assess what would be a reasonable rent for the lessees to pay but what is a reasonable rent for the premises. That, when assessed, is payable by the lessees. If the effect of the improvements on the rent payable is to be disregarded, then the lessees will not be paying a reasonable rent for the demised premises but a reasonable rent for the demised premises less the improvements; but it is recognised that the improvements are part of the demised premises. If the effect on the rent of the improvements is to be disregarded then in my opinion an express provision is required to effect that as was necessary in the Landlord and Tenant Act. ${ }^{17}$

Wilberforce L.J. and Salmon L.J. wrote dissenting judgments in Ponsford holding that the words "reasonable rent" meant that the rent was to be determined based on what is reasonable between the parties. They found that it was reasonable between the parties to disregard the value of the improvements since the tenant had paid for such improvements. Wilberforce L.J. and Salmon L.J. clearly placed a greater emphasis on the words "reasonable rent" than on the words "for the demised premises." According to Wilberforce L.J., the words "for the demised premises" added nothing to the clause. The emphasis which he placed on the words "reasonable rent" is demonstrated in the following passage from his judgment: 
My Lords, clear words may sometimes force the courts into solutions which are unjust and in such cases the courts cannot rewrite the contract. This is not such a case: in my opinion logic and justice point in the same, not opposite, directions. I cannot attribute any other meaning to "reasonable rent" in this context than one which takes into account (or disregards) what any lessor, any lessee, or any surveyor would consider it reasonable to take into account (or disregard). In this case the surveyor should disregard any effect on rent of improvements carried out (viz. paid for) by the lessee. ${ }^{\text {k }}$

\section{Salmon L.J. supported Wilberforce L.J's interpretation:}

This appeal turns solely upon the true meaning of the words "a reasonable rent." Considerable stress was laid by Mr. Price and the majority of the Court of Appeal on the words "for the demised premises." I am afraid that I do not understand how those words can afford any real help in construing the words "a reasonable rent" as used in the lease. After all, the rent fixed by the lease could hardly be a rent for anything other than the demised premises.... By a well established legal principle the extension and improvements became part of the demised premises, but this does not mean that in assessing a reasonable rent for the tenant to pay, it would be possible to increase the rent because of the additions and improvements to the landlord's premises which the tenant had made at his own expense.

The case for the landlords really turns on the argument, with which I disagree, that "a reasonable rent" for the demised premises must mean the open market rent for the demised premises. If the parties had meant the open market rent, they would, no doubt, have said so, as they usually do."

While the rent review clause in Ponsford is clearly fraught with ambiguity, the decision of the majority of the House of Lords is persuasive in its reasoning. If a rent review or renewal clause provides that the rent payable is to be based on what is a "reasonable rent as between the parties," then such a clause calls for a subjective approach. There is no reference to an objective standard upon which the rent is to be assessed. If the clause calls for the rent to be agreed upon by the parties based on what is a "reasonable rent for the demised premises," there is an objective standard upon which the rent is to be assessed. While the word "reasonable" suggests that some notion of faimess must be considered, the proper interpretation of such a clause is to examine what is a reasonable rent for the demised premises and not what is reasonable as between the parties. The approach adopted by the majority of the House of Lords in Ponsford was applied by the English Court of Appeal in Basingstoke and Deane Borough Council v. Host Group Ltd. ${ }^{20}$

The basic distinction between the rent review clause in Thomas Bates and the rent review clause in Ponsford was concisely stated in the 1983 decision of the English Queen's Bench in Lear. ${ }^{21}$ In that case, the rent renewal clause provided that the rent for the renewal term was to be "a rent to be agreed between the parties hereto or in 
default of agreement at a rent to be determined by a single arbitrator...." 22 The issue was whether the rent should be based on an open market rent or a fair rent as between the particular landlord and tenant involved in the rental dispute. The English Court of Queen's Bench found that the clause was similar to the clause in Thomas Bates and radically different from the clause in Ponsford. Evans J. held that the material difference between the clause before him and the clause in Ponsford was that the clause in Ponsford called for rent to be determined without reference to an agreement between the parties, that is, the rent was to be based on a "reasonable rent for the demised premises." He summarized his reasons in the following passage:

Counsel for the tenant points out that the option in Thomas Bates \& Son Lid. v. Wyndham's (Lingerie) $L t d$., with immaterial differences, is indistinguishable from the language of the option clause in the present case. But it was the review clause which fell to be construed in that case. Even so, 1 can find no material difference in the language and its effect. The option clause is radically different from the clause which had to be construed in Ponsford v. HMS Aerosols Lid. It seems to me that in the present case the emphasis in the clause is on what is to be agreed between the parties, and the arbitrator is required to determine what it would be reasonable for these landlords and this tenant to agree in all the circumstances of the case. I think that it was the intention of the parties to the lease that, in default of agreement between them, the arbitrator should determine a rent which it would have been reasonable for these landlords and this tenant to agree and to take into account all the considerations which would affect the minds of the parties. In other words, the test to be applied is subjective and not objective. ${ }^{23}$

The lesson to be learned from the decisions in Thomas Bates, Ponsford and Lear is that if a landlord wants to ensure that it receives "market rent" from a tenant for a review period or renewal term, it should clearly set out in the rent review or renewal clause that the rent shall be agreed upon by the parties based on what is the "open market rent" for the leased premises. A landlord should avoid qualifying those words with such words as "fair" or "reasonable" as they simply add ambiguity to the term "market rent." The use of the word "fair" might result in the tenant arguing that "fair" meant a "market rent" which was fair to the tenant and allow the tenant to adduce evidence of a number of factors which might result in the arbitrator in assessing the rent payable below the open market rent.

\section{RESTRICTION ON USE CLAUSES}

As a general rule, the more restrictions placed on the tenant's use of the leased premises, the lower the rent such premises will attract on the open market. If the tenant is limited to one particular use of the leased premises, there are fewer potential tenants for the premises, limiting the demand for such premises. Also, the restriction on use may not be the highest and best use of the leased premises. Not surprisingly, landlords attempt to have the best of both worlds by inserting words in a rent review or renewal clause which provide that the rent payable for the review period or renewal term shall be the "market rent" for the leased premises taking into account the terms of the lease, but excluding any regard for the restrictions placed on the tenant's use of the leased 
premises. The courts have generally held that if landlords wish to avail themselves of this favourable interpretation, they must clearly set out in the rent review or renewal clause which clauses in the lease are to be disregarded. ${ }^{24}$ The rule of construction is that the parties are presumed to have intended that the rent for a review period or a renewal term is to be assessed by taking into account the terms and conditions of the lease, unless the parties expressly or impliedly otherwise agree. ${ }^{25}$

In Basingstoke, the English Court of Appeal was asked to interpret a rent review clause which provided that the rent for the review period was to be "the reasonable then current ground rental value" based on "the rental value of the demised premises." 26 The issue was whether the valuer, in interpreting this clause, should do so on the basis that the premises were available at the date of assessment for letting on the terms and conditions of a hypothetical lease containing: (a) such terms and conditions as the valuer regards as reasonable for a lease of a bare site for development at the relevant date; or (b) such terms and conditions as the original lease. Nicholls L.J. held that the rent should be assessed taking into account the terms of the existing lease. He stated:

We approach the construction of para (vii), therefore, on the footing that, unless the paragraph otherwise requires, expressly or by necessary implication, or there is some context indicating otherwise, the parties are to be taken to have intended that the notional letting assumed for the purposes of the rent review assessment was to be on the same terms (other than as to quantum of rent) as those still subsisting under the actual, existing lease. ${ }^{27}$

\section{Nicholls L.J. further noted:}

Of course rent review clauses may, and often do, require a valuer to make his valuation on a basis which departs in one or more respects from the subsisting terms of the actual existing lease. But if and in so far as a rent review clause does not so require, either expressly or by necessary implication, it seems to us that in general, and subject to a special context indicating otherwise in a particular case, the parties are to be taken as having intended that the notional letting postulated by their rent review clause is to be a letting on the same terms (other than as to quantum of rent) as those still subsisting between the parties in the actual existing lease. The parties are to be taken as having so intended, because that would accord with, and give effect to, the general intention underlying the incorporation by them of a rent review clause into their lease. ${ }^{28}$

See e.g. Basingstoke; and Leighton v. Canada (1987), [1988] 13 F.T.R. 198 (F.C.T.D.) [hereinafter Leighton]. For a general discussion on the effect of restriction on use clauses on rent see A.K. Mitchell, Q.C. \& J. Ferac "Lease Arbitrations" in Commercial Leases - 1995 Update, supra note 3 at 3.1 .

See Basingstoke; Plinth Property Investments Lid. v. Mott, Hay \& Anderson (1978) 38 P.\&C.R., 361 (C.A.) [hereinafter Plinth]; Temple \& Crook Lid. v. Capital \& Counties Property Co. Lid. 2 E.G.L.R. 129 [hereinafter Temple \& Crook]; Trusthouse Forte Albany Hotels Lid. v. Daejan Investments Lid. (No. 2) [1989] I E.G.L.R. 133. 
In Plinth ${ }^{29}$ which was about ten years prior to the decision in Basingstoke, the English Court of Appeal unanimously upheld the decision of an arbitrator who took into account a restriction on use clause in determining the rent payable for the renewal term of a lease. In that case, the lease stated that the tenant was not to use the leased premises other than as office space in carrying on its business as consulting engineers. The arbitrator significantly reduced the rent payable based on the effect of a restriction on use clause. There was much debate during the arbitration as to whether the arbitrator should take into account the restriction on use clause in assessing the rent payable. The arbitrator stated in his award that, in the event he was wrong and should not have taken into account the restriction on use, he determined that the rent payable was substantially higher than if the restriction on use clause was taken into consideration. The arbitrator's award was appealed to the English Court of Appeal which found that the arbitrator adopted the correct approach when he assessed the rent payable taking into account the restriction on use clause. Denning M.R. stated:

One of the important provisions of the underlease is a restriction on the underlessees: "Not to use the demised premises or any part thereof or suffer the same to be used otherwise than as offices ... in connection with the lessee's business of consulting civil engineers." It seems to me that this restriction would affect very seriously any rent that the lessee would pay for the premises. He would not pay anywhere near the full market rent if his use of the premises was restricted to the business of civil engineers. For instance, he could not underlet them to a chartered accountant or any other professional person or to a business firm."

A similar approach was adopted by the English Court of Chancery in Temple \& Crook $^{31}$ which cited with approval the decision in Plinth.

The decision in Basingstoke was followed by the Ontario Divisional Court in $R e$ Canadian National Railway Co. and Inglis Ltd. ${ }^{32}$ where the Court was faced with the question of whether a clause in a lease which restricted a tenant's use of the leased premises for manufacturing purposes should be taken into account in determining the rent payable for a renewal term. The lease provided that the rent for the renewal term was to be set by the landlord based on what was a "fair and equitable" rent and, in the event that the parties could not agree, it was to be determined by arbitration. The landlord set a "fair and equitable" rent based on the highest and best use of the leased premises, which was not manufacturing.

The Court in Inglis quoted extensively from the judgment of Nicholls L.J. in Basingstoke. The Court found that the restriction on use clause must be considered in determining the rent payable. Farley J. held that there was nothing in the lease which explicitly stated that the rent was to be determined on an unrestricted highest and best use basis. Farley J. stated:

32 (1992), 93 D.L.R. (4th) 461 (Ont. Div. Ct.) [hereinafter Inglis]. 
Certainly, as to the rental to be determined by C.N. there is nothing which explicitly says that it is to be determined on an unrestricted highest and best use basis. It is obvious that if the parties had wished to put this condition in the renewal that it would have been very simple for them to have so specified in a few words."

While the Federal Court of Canada in Leighton ${ }^{34}$ did not deal with a restriction on use clause, the decision is useful in showing what other clauses in a lease a court may take into account in assessing the rent payable. The rent review clause in Leighton stipulated that every five years the rent payable was to be "a fair market rent for the land leased on the terms and conditions contained in this lease ... or the same rent in each year as for the last year of the previous five year period." 35 The issue before the Court was whether the rent payable for a review period must be assessed taking into account certain clauses in the lease, including a clause restricting the tenant's ability to assign the lease, a clause which prohibited the tenant from mortgaging the lease without the prior written consent of the landlord and a clause which made the lease subject to the Indian Act. ${ }^{36}$ The leased premises in that case were part of the Little Shuswap Indian Band's reserve.

The Court in Leighton held that the fact that the lease was subject to the Indian Act and the fact that there were restrictions in the lease on the assigning and encumbering the lease were factors which should be considered in assessing the rent payable for the rent review period. Muldoon J. stated that any comparison of the leased premises to the market rent without reference to these terms was patently spurious, especially in light of the words in the rent review clause which provided that the rent was to be for land "leased on the terms and conditions contained in this lease." ${ }^{37}$

In contrast to the decisions in Basingstoke, Plinth and Temple \& Crook, the British Columbia Court of Appeal in No. 100 Sail View Ventures Ltd. v. Janwest Equities $L t d^{38}$ held that a restriction on use clause in a lease was to be disregarded in assessing the rent payable under a rent review clause which called for the assessment to be based on "fair market value of the Leased Premises as bare land." The Court held that the parties intended that the assessment be made without reference to the lease as the words "bare land"39 implied that there was no lease encumbering the land. Clearly, the Court of Appeal placed a great deal of emphasis on the words "as bare land." Hollinrake J.A. stated:

With respect, I think that the phrase "fair market value of the Leased Premises as bare land" must be interpreted in this case as necessarily inferring that the valuation be done without reference to the lease and consequently without reference to the restriction on use found in the lease. In my opinion if the parties intended to include as a factor in the valuation of base rent the restricted use they would have

Ibid. at 478.

Supra note 24.

$\mathrm{Ibid}$. at 200 [emphasis added].

R.S.C. 1985, c. 1-5.

Ibid.

(1993), 84 B.C.L.R. (2d) 273 [hereinafter Janwest Equities].

Ibid. at 275. 
expressly said so in words that would have modified the words "bare land." I think that to factor in the lease or the restricted use in it would result in the landlord being denied the fair market value of the land "as bare land." 410

Hollinrake J.A. referred to the decision in Basingstoke, but declined to follow it. Since Basingstoke also referred to the rent being assessed as "a bare site," the decision in Janwest Equities calls into question in British Columbia the approach adopted by the English Court of Appeal in Basingstoke when faced with the words "as bare land" or "as a bare site" in a rent review or renewal clause. It is difficult to understand the reasoning of the majority in Janwest Equities and its conclusion that bare land means land unencumbered by a lease. A more logical interpretation is that bare land means land without buildings constructed thereon since there can be bare land encumbered by a lease restricting its use. This interpretation was made by the Ontario Divisional Court in Revenue Properties Co. v. Victoria University. ${ }^{41}$ Based on the decisions in Plinth, Janwest Equities and Temple \& Crook, it is evident that if a landlord wishes for the assessment to be made without reference to the lease encumbering the land, it should expressly state this in the rent review or renewal clause.

Where the tenant has the ability under a lease to change its use of the leased premises with the consent of the landlord, the question which arises is whether a court or arbitrator can assume that the landlord would consent to other uses of the leased premises and, therefore, the rent can be assessed based on these other uses of the leased premises. Generally speaking, the ability of a landlord to consent to other uses under a lease should not be taken into account in assessing the rent payable, unless the parties have otherwise agreed or the tenant has changed the use and the landlord has consented to such change or the landlord has waived such restriction. The English Court of Appeal in Plinth rejected an argument put forth by the landlord that the restriction on use clause should not be taken into account since the landlord might possibly relax or waive the restriction on use clause during the term of the lease.

There is some support in the case law for the view that other potential uses of the leased premises by the tenant may be considered in assessing the rent payable where the lease contemplates other uses. ${ }^{42}$ Gibson J. in the English Court of Chancery decision of Forte \& Co. suggested that it was open for the valuer in that case to take into account the fact that a hypothetical lessee would pay more for a lease which expressly contemplated a change of use. He distinguished the decision in Plinth on the ground that the wording of the rent review clause in Plinth contemplated only one form of use and that the decision in Plinth did not apply to a case where the lease expressly contemplated that other forms of use might be authorized. Gibson J. stated:

The decision in the Plinth case in my view turned on the particular wording in the particular lease which permitted only one form of user. It does not follow that the decision applies to a case where the

lbid. at 280.

(1993), 101 D.L.R. (4th) 172 (Ont. Ct. (Gen Div.)).

See Forte \& Co. Ltd. v. General Accident Life Assurance Ltd., [1986] 2 E.G.L.R. 115 [hereinfater

Forte \& Co.]; R. v. Meyer (1990), 10 R.P.R. (2d) 1 (F.C.T.D.). 
lease expressly contemplates that other forms of user might be authorised. Of course it would be open to the arbitrator to say that the possibility of the superior lessors acting arbitrarily, as they are entitled to do, when asked for their authority has the effect in valuation terms that the rental value has to be assessed on the footing that the specified forms of user are the only permitted forms of user. But equally, in my judgment, if he were to say that the hypothetical lessee would pay more for a lease which expressly contemplated the possibility of a change of use, I do not see that he could be faulted. If in reality that is something that would be taken into account as an appreciatory factor, I see no basis on which it should be excluded. ${ }^{43}$

Notwithstanding the view expressed by Gibson $\mathrm{J}$. in Forte \& Co., a more logical approach is for an arbitrator to disregard the possibility of a change of use where the rent review or renewal clause restricts the tenant's use of the leased premises, unless the clause expressly sets out that the assessment is to be made based on other possible uses. A rent review or renewal clause usually calls for the rent to be assessed as of the date of the beginning of the review period or renewal term. If an arbitrator were to take into account the possibility of the landlord relaxing or waiving the restriction on use clause at some point in the future, the arbitrator would not be assessing the rent as of the assessment date. This was the view of the English Court of Appeal in Plinth which cited with approval the following passage from the judgment of the trial judge, Slynn J., who stated:

In my judgment, the arbitrator in the present case was right to follow the words of the underlease that he should have regard to rental values of property then current and to the provisions of the underlease other than the rents thereby reserved, and he took, in my judgment, the right course in valuing on that basis. I do not consider that he was required to consider whether it would be more or less likely that consent would be given for a change of user, or for what purpose the change of user might take place, or to whom and to what extent the property might be underlet or assigned. Nor is he required to value the extent to which any of those events would affect the proper rental of the lease. It seems to me clear that, if the landlord wants a higher rent, which greater freedom given to a tenant apparently attracts, then he provides for that by the terms of the lease itself. ${ }^{\text {t4 }}$

Given this interpretation and the potential impact that a restriction on use clause can have on lowering the rent payable, a landlord will want to ensure that the rent review or renewal clause expressly states that the restriction on use is to be disregarded by the arbitrator in assessing the rent payable.

\section{SAMPLE CLAUSES}

In preparing a rent review or renewal clause for a landlord, the drafter should ensure that the rent payable for the review period or renewal term is determined by the "market rent" for the leased premises, including all leasehold improvements, and that the parties or the arbitrator shall not take into account any cash payments, leasehold improvement allowances, rent-free periods or other inducements made by the landlord 
to the tenant during the previous review period or lease term. ${ }^{45}$ An example of a rent renewal clause favouring a landlord is as follows:

If the tenant has performed on a timely basis all the tenant's covenants and is not in default under any of the terms of this lease, then the tenant, on giving written notice to the landlord not earlier than months and not later than _ months prior to the last day of the term of this lease, shall have the right to renew this lease for a renewal term of _ years upon the same terms and conditions as contained in this lease, except the rent payable and this right of renewal. The rent payable during the renewal term shall be at the then current market rent for the leased premises for its highest and best use, including all leasehold improvements, and no reduction shall be made to such market rent by taking into account the restriction placed on the tenant's actual use of the leased premises, or any cash payment, leasehold improvement allowance, rent-free period or other inducement payment given by the landlord to the tenant and provided further that the annual rent for the renewal term shall not be less than the aggregate annual rent payable during the last completed year of the term. Failing agreement by the parties on the market rent for the leased premises within _ days prior to the expiry of the term of this lease, such market rent shall be determined by arbitration, based on the criteria set out above, by a single arbitrator pursuant to the provisions of [insert name of arbitration statute], or any like statute in effect from time to time, and the decision of such arbitrator shall be final and binding upon the parties. The costs of such arbitration shall be borne equally by the parties. Until the rent for the renewal term has been determined, the tenant shall continue to pay the monthly instalments of rent payable before the commencement of the renewal term, and upon such determination, the landlord or the tenant, as the case may be, shall make the appropriate adjustment payment to the other together with interest thereon from the commencement of the renewal term until the date of payment at the rate of interest equal to _\% per. annum, calculated semi-annually, not in advance. The provisions of this clause shall be determined to be a submission to arbitration within the provisions of the [insert name of arbitration statute], or any like statute in effect from time to time.

In preparing a rent review or renewal clause for a tenant, a drafter will want to include as many subjective factors as possible in the determination of the rent payable. An example of a rent renewal clause favouring a tenant is as follows:

The tenant, on giving written notice to the landlord not earlier than _ months and not later than months prior to the last day of the term of this lease, shall have the right to renew this lease for a renewal term of _ years upon the same terms and conditions as contained in this lease, except the rent payable and this right of renewal. The rent payable during the renewal term shall be a reasonable rent as between the landlord and the tenant, taking into account all factors which may be relevant to the landlord and the tenant. Failing agreement between the parties on a reasonable rent within _ days prior to the expiry of the term, such rent shall be determined by arbitration, based on the criteria set out above, by a single arbitrator pursuant to the provisions of the [insert name of arbitration statute], or any like statute in effect from time to time, and the decision of such arbitrator shall be final and binding on the parties. The costs of the arbitration shall be borne equally by the parties. Until the rent for the renewal term has been determined, the tenant shall continue to pay the monthly instalments of rent payable before the commencement of the renewal term. The provisions of this clause shall be 
determined to be a submission to arbitration within the provisions of the [insert name of arbitration statute], or any like statute in effect from time to time. ${ }^{46}$

\section{CONCLUSION}

Careful drafting of rent review or renewal clauses can avoid much confusion with respect to the approach to be taken by an arbitrator in determining the rent payable under a lease. The standard upon which the arbitrator is to determine the rent payable should be expressly set out. If the arbitrator is to assess the rent based on the "market rent," then the parties should avoid the use of other words, such as "reasonable" and "fair," as these words merely add ambiguity to the clause. The factors which the arbitrator is to include or exclude in making his assessment should also be clearly stated in the rent review or renewal clause.

Where a tenant has expended or intends to expend large sums of money on tenant's improvements which will increase the value of the leased premises, a tenant will want to carefully review its lease to determine which approach an arbitrator will take in interpreting a rent review or renewal clause. A tenant is often shocked to find that on a renewal term it must pay a higher rent due to these improvements which it installed at its own expense since the rent review or renewal clause speaks of rent being based on a prevailing "market rent" for the leased premises, as improved. 